\title{
Heterogeneity Effects of Glycan Clusters on Microarrays and Dendrimers
}

\author{
マイクロアレイ上やデンドリマー上での不均一な糖鎖クラスター効果
}

Key Words: heterogeneity, glycoform, cluster, microarray, dendrimer

Interaction of single molecules of glycans (monomeric glycans) with sugar-binding proteins is generally weak ( $\sim \mathrm{mM}$ levels). Most glycans in nature, therefore, enhance their interactions by forming glycoclusters. These enhanced interactions are referred to as cluster effects or multivalency effects. Many researchers have utilized proteins, polymers, dendrimers, and microarrays as platforms for chemically mimicking the natural glycocluster environment. However, natural glycoclusters often consist of several kinds of glycans (called glycoform), and this creates a highly diverse glycobioenvironment. Such heterogeneous glycoclusters may be responsible for enhancing glycan-dependent interactions and regulating or adjusting biological responses in vivo. Many reports have described the cluster effects of homogeneous glycoclusters; however, very few reports have clearly described the effects of neighbors in heterogeneous clusters. Wong, $\mathrm{Wu}$, and co-workers recently prepared heterogeneous clusters consisting of 2 different glycans on microarrays as well as on dendrimer templates. They experimentally exemplified the enhanced and/or the decreased interactivity towards antibodies, that were sensitively affected by the neighboring glycans in the heterogeneous structures [Liang, C.-H. et al. (2011) Angew. Chem. Int. Ed. 50, 1608-1612].

These authors initially screened the interaction between the Gb5 glycan and the anti-stage-specific embryonic antigen 3 (anti-SSEA3, or described as anti-Gb5) antibody on a microarray, as a model for heterogeneous cluster interactions. The glycans immobilized on microarrays mimic natural glycan clusters and enhance interactions with glycaninteracting proteins. To create the experimental glycoclusters, they immobilized the following amine-linked glycans on $\mathrm{N}$-hydroxysuccinimide (NHS)-activated glass slides: (1) Gb5 glycan alone and (2) Gb5 in combination with SSEA4, Globo $\mathrm{H}, \mathrm{Gb} 4, \mathrm{~Gb} 3, \mathrm{~Gb} 2$, or $\mathrm{Bb} 2$ (in the decreasing order of length and steric bulk). The authors simply mixed an equimolar amount of each component and spotted the mixture on the slide. The Gb5 glycan constituent on each spot was adjusted to a constant $5 \times 10^{-14} \mathrm{~mole} / \mathrm{spot}$, and the neighboring effects of different glycans on antibody interactivity were investigated by treating the array with fluorescence-labeled anti-Gb5 antibody. When longer and bulkier glycans were coimmobilized with Gb5, the antibody interacted less efficiently
単分子の糖鎖と糖鎖認識タンパク質との相互作用は一般 に弱い。そこで生体内での多くの糖鎖はクラスターを形成し て糖鎖相互作用の強度を増強する (クラスター効果)。これま でに、糖鎖をタンパク質、ポリマー、デンドリマー、あるい はマイクロアレイ上に担持することによって、生体内での糖 鎖クラスター環境を疑似化して、その相互作用を向上させる 試みがなされてきた。一方、生体内糖鎖の多くは不均一であ り (グライコフォーム)、クラスター形成下で多様性の高い糖 鎖生体分子社会を作り出して、糖鎖相互作用の強度や選択性 を増強するとともに、糖鎖依存的な動態や機能を微妙に調節 していると考えられている。単一糖鎖からなるクラスター効 果の例は多く報告されているのに対して、複数の糖鎖がレセ プターとの相互作用や生体内での動態に及ぼす効果について は明確には示されていなかった。最近、C.-H. Wong およびC.-Y. $\mathrm{Wu}$ らによって、マイクロアレイ上で 2 種類の糖鎖からなる 不均一な糖鎖クラスターが化学的に構築され、単一糖鎖から なるクラスターと比較して、抗体との相互作用が明確に向上、 または低下する現象が報告されたので紹介したい [Liang, C.-H. et al. (2011) Angew. Chem. Int. Ed. 50, 1608-1612]。

著者らはまず、Gb5 糖鎖と anti-SSEA3 抗体（stage-specific embryonic antigen 3、Gb5）との相互作用をモデルとして、 マイクロアレイの手法を活用してスクリーニングした。アレ イ上に糖鎖を担持することによって、糖鎖クラスター環境が 構築され、糖鎖認識タンパク質との相互作用が向上すること が知られている。スクシンイミジルエステルで活性化された ガラススライドに対して、アミンリンカーを持つ単一の Gb5 糖鎖（コントロール）、拈よび Gb5 に加えてもう一種の糖鎖 (SSEA4、Globo H、Gb4、Gb3、Gb2、㧍よびBb2：この順に 糖鎖の長さが短くなり、または嵩が低くなる）を等量ずつ混 合してスポット上に担持した。この際、各スポットに担持し た Gb5 糖鎖のモル数を全て $5 \times 10^{-14} \mathrm{~mole} / \mathrm{spot} に$ 固定し、他 の糖鎖の存在が $\mathrm{Gb5}$ 糖鎖クラスター環境に与える影響を調心゙ た。蛍光標識されたanti-Gb5 抗体を用いて各スポットとの相 互作用を検討したところ、単一の Gb5 糖鎖のみを担持するよ りも、構造がより伸張し、そしてょり嵩の高い糖鎖を併せて 
with Gb5 than in the homogeneous Gb5 spot, except in the case of $\mathrm{Gb} 3$, which showed a stronger interaction than expected from the trend. However, the heterogeneous spot created by co-immobilization with the largest SSEA4, which contains the additional $\mathrm{N}$-Ac-neuramic acid linked to the C3hydroxy of the non-reducing galactose of Gb5, exhibited an unexpectedly stronger interaction with the antibody than the homogeneous Gb5 control. On the basis of this initial screening, they repeatedly immobilized homogeneous Gb5 and SSEA4 glycan spots, as well as heterogeneous Gb5/ SSEA4 glycan spot, on slides and evaluated the interaction with the anti-Gb5 antibody. The authors concluded that the efficiency of SSEA4 interactions with the antibody is similar to that of Gb5. Therefore, the sialic acid in SSEA4 has a negligible effect on antibody affinity. More importantly, the heterogeneous Gb5/SSEA4 cluster exhibited a stronger interaction with the antibody than either of the homogeneous clusters on the slide; this indicated a positive effect of the neighboring glycan on the parent glycan/receptor interaction.

In contrast, when the Gb3 glycan, which did not show an apparent interaction with the anti-Gb5 antibody, was coimmobilized with Gb5 on the slide, the antibody binding decreased in parallel to the amount of Gb3 immobilized on the spots. Gp120 is an envelope glycoprotein of HIV that is covered by the high-mannose-type $N$-glycan clusters on the protein surface, and this allows it to escape detection by the immune system. The decreased affinity of the Gb5/Gb3 heterogeneous cluster on the slide may chemically mimic the protecting effects of the heterogenic clusters in nature, i.e., negative effects of heterogeneity.

These authors also presented the result of their investigation of heterogeneous high-mannose-type glycodendrimers with anti-2G12, an antibody of the highmannose-type $\mathrm{N}$-glycans in gp120. Two truncated structures of the high-mannose-type $N$-glycans with anti-2G12 antibody interactivity, i.e., the Man4 and Man9 motifs, were randomly introduced on the AB3-type dendrimer by using the $\mathrm{Cu}(\mathrm{I})$ catalyzed Huisgen [3+2]-cycloaddition method of preparing glycodendrimers (a maximum of 9 molecules of the glycans can be loaded) [Wang, S.-K. et al. (2008) Proc. Natl. Acad. Sci. USA 105, 3690-3695]. Various heterogeneous glycodendrimers were synthesized with different ratios of the 2 glycans. The heterogeneous glycodendrimers with a Man4 to Man9 ratio of 5:4 showed the highest interaction with the antibody. The authors succeeded in chemically preparing heterogeneous glycoclusters in both microarrays and dendrimeric templates, thus showing that heterogeneity can contribute both positively and negatively to receptor interaction.

Recently, we investigated the noninvasive imaging of $\mathrm{N}$-glycans and found that glycan valency, i.e., the use of
導入することにより、次第に anti-Gb5 抗体との相互作用が低 下する傾向が見られた（例外として、Gb3 糖鎖を併せて導入 した場合には比較的強い相互作用を示した)。しかし、最も糖 鎖構造が伸張しているにも拘らず、非還元末端にシアル酸を 含む SSEA4（Gb5 糖鎖構造に対して、非還元末端のガラクトー スの 3 位に $N$ - アセチルノイラミン酸が結合した構造）と共 に担持した不均一糖鎖クラスター（Gb5/SSEA4）のスポット では、Gb5のみ担持したスポットよりも格段に強い相互作用 を示すことが判明した。この知見を基にして、改めて Gb5 糖 鎖、およびSSEA4 糖鎖の均一糖鎖クラスター、さらに Gb5 と SSEA4 の不均一糖鎖クラスター構造をマイクロアレイ上に導 入し、anti-Gb5 抗体との相互作用を評価したところ、Gb5 糖 鎖だけではなく、SSEA4 糖鎖もanti-Gb5 抗体に対してほぼ同 程度の反応性を示し、さらに Gb5/SSEA4 不均一糖鎖クラス ターでは格段に高い反応性を示すことを明らかにした。

一方、anti-Gb5 抗体とは相互作用を示さなかった Gb3 糖 鎖についても Gb5 糖鎖に対してその割合を種々変化させてア レイ上に担持したところ、Gb3 糖鎖の担持量依存的に抗体に 対する反応性が低下することを見出した。HIV のエンベロー プ糖タンパク質 gp120 では、その表面をクラスター状にハイ マンノース型糖鎖が覆っており、この糖鎖の立体障害により、 免疫システムによる捕捉や攻撃から保護している。本論文の 結果を広く捉えれば、Gb5 と anti-Gb5 抗体との相互作用をモ デルとして、マイクロアレイ上で糖鎖クラスターによる保護 効果を化学的に再現したと言えよう。

さらに著者らは、gp120のハイマンノース構造に対する 抗体である anti-2G12 抗体と、化学的に合成した不均一なハイ マンノース型糖鎖デンドリマーとの相互作用も検討している。 まず、ハイマンノース型 $N$ - 型糖鎖の部分構造であり、anti2G12 抗体に対して反応性を示す 2 種類の Man4 と Man9 糖鎖 の混合物を用いて、AB3 タイプのデンドリマー基質（9分子 の糖鎖が導入できる）に対してランダムに導入した（グライ コデンドリマーの合成法 : [Wang, S.-K. et al. (2008) Proc. Natl. Acad. Sci. USA 105, 3690-3695])。これら 2 種類のハイマンノー 久型糖鎖の割合が異なる様々な不均一糖鎖デンドリマーと anti-2G12 抗体との相互作用を検討した結果、平均して Man4 とMan9が5：4の割合で導入されたデンドリマーが、最も 強い相互作用を示した。以上のように、マイクロアレイ、掠 よびデンドリマー上に不均一な糖鎖クラスター環境を構築し、 糖鎖の不均一性が糖鎖認識タンパク質との相互作用に抢いて、 あるときには正に、またあるときには負に働くことを明らか にした。

本レポーターらも最近、 $N$ - 結合型糖鎖の生体内イメージ 
structurally defined $N$-glycodendrimers, sensitively affects their organ-specific accumulation and excretion pathway [Tanaka, K. et al. (2010) Angew. Chem. Int. Ed. 49, 8195 -8200]. The imaging results also indicate a promising possibility for future development of glycan-based imaging tracers. These tracers would selectively target specific tumors or inflammation, even in the presence of various biomolecules in vivo if structurally defined heterogeneous glycoclusters can be synthesized. By applying the glycocluster preparation to microarrays or dendrimeric templates, various heterogeneous glycocluster environments can be constructed in a combinatorial fashion. This approach provides a promising strategy for developing novel glycan-based vaccine adjuvants, virus-neutralizing drugs, and glycan-based diagnostic tracers. Heterogeneous glycocluster synthesis so far reported can be used to approximately estimate the average ratio between a few different glycans on an array or within dendron structures. Nevertheless, they cannot precisely define the spatial relationship between neighboring glycans in the clusterized structures. They are still structurally undefined, random heterogeneous glycoclusters. In order to evaluate the heterogeneity of natural glycoclusters in detail, glycochemists should consider how structurally defined homogeneous heterogeneous glycoclusters could be prepared efficiently and rapidly by using techniques such as the combinatorial approach. Our ability to fully investigate glycocluster heterogeneity depends on how many organic reactions can be developed that are truly orthogonal to the functional groups.

\section{Reported by Katsunori Tanaka}

Department of Chemistry, Graduate School of Science, Osaka University

1-1 Machikaneyama, Toyonaka, Osaka 560-0043, Japan

E-mail: ktzenori@chem.sci.osaka-u.ac.jp

FAX: 81-6-6850-5419
ングに扔いて、それらの臟器選択的な集積や体外排出過程を 効率良く可視化するためには、ある一定以上の価数 (valency) を持つ糖鎖デンドリマーを用いることが重要であることを 見出している [Tanaka, K. et al. (2010) Angew. Chem. Int. Ed. 49, 8195-8200]。さらに不均一な糖鎖デンドリマーを用いることに よって、様々な分子が混在する生体内に打いても癌や炎症組 織に効率的かつ選択的に集積する画期的な糖鎖誘導体を構築 できる可能性を示した。今回紹介したような糖鎖マイクロア レイやデンドリマー合成法を用いることによって、将来、糖 鎖の不均一なクラスター環境がコンビナトリアル的に構築さ れ、ワクチンのアジュバントやウイルスの中和分子、または 診断薬の創製研究に対して、革新的な戦略を与えよう。しかし、 今回の報告を含めた従来のアレイ上やデンドリマー上の不均 一な糖鎖クラスターは、クラスターを構成する異なる糖鎖構 造の“平均的な割合”を揃えることはできるが、隣接する 異なる糖鎖の配置まで厳密に制御することはできない。已然、 “ランダム”な不均一糖鎖クラスターなのである。糖鎖の不 均一性、または生体内でのグライコフォームを厳密に解析す るためには、今後、“均一”な構造を持つ不均一なクラスター 構造を如何にして効率的に合成することができるかがポイン 卜となる。言わば不均一性を構成する糖鎖構造の数に対応す るどれだけ多くの “官能基直行性” ある有機合成反応を開 発することができるか、これが今後の糖鎖合成化学者に求め られる大きな課題である。

田中克典 大阪大学大学院理学研究科 